\title{
IDENTIFIKASI KELIMPAHAN JENIS SATWA MANGSA HARIMAU SUMATRA (Panthera tigris sumatrae) MENGGUNAKAN KAMERA JEBAK DI RESORT TALANG LAKAT TAMAN NASIONAL BUKIT TIGA PULUH
}

\author{
Identification of the Abundance of Sumatran Tiger Prey Species \\ (Panthera tigris sumatrae) by Using Camera Traps at Talang Lakat Resort \\ Bukit Tiga Puluh National Park \\ Andy Foulton ${ }^{1}$, Defri Yoza ${ }^{2}$, Yossi Oktorini ${ }^{2}$ \\ ${ }^{I}$ Mahasiswa Jurusan Kehutanan, Fakultas Pertanian, Universitas Riau, Jl. Bina Widya Km 12.5 \\ Pekanbaru, Riau 28293 Telp: 0761-63272/Fax: 0761-566821 \\ E-mail: andy.foulton@gmail.com \\ ${ }^{2}$ Dosen Jurusan Kehutanan, Fakultas Pertanian, Universitas Riau, Jl. Bina Widya Km 12.5 \\ Pekanbaru, Riau 28293 Telp: 0761-63272/Fax: 0761-566821 \\ E-mail:defri.yoza@gmail.com,oktorini.yossi@yahoo.com
}

Diterima: 27 Juli 2021, Direvisi: 02 Agustus 2021, Disetujui: 28 Januari 2022

DOI: 10.31849 /forestra.v17i1.7402

\begin{abstract}
Bukit Tiga Puluh National Park is one of the national parks in Indonesia used as a conservation area for the sumatran tiger. The existence of the sumatran tiger is not separate from the ability of forest areas to provide habitat components, such as sources of food, water, and shelter. This research aimed to identify the animal species and abundance of sumatran tiger prey species at Talang Lakat Resort, Bukit Tiga Puluh National Park. Data collected by camera trap as primary data and secondary data collected at the Bukit Tiga puluh National Park Hall. The data were analyzed using the formula of species abundance and encounter rate. Based on the data results, there are five types of sumatran tiger prey recorded by camera traps in 2020, such as Helarctos malayanus, Macaca nemestrina, Argusiana argus, Hystrix Brachyura, and Muntiacus muntjak. The prey species with the highest species abundance and RAI values in 2020 were Macaca nemestrina with a species abundance value of $40 \%$ and RAI 14 photos/day, while the lowest species abundance values were Helarctos malayanus with a value of $7 \%$ and RAI 5 photos/day.
\end{abstract}

Keywords : sumatran tiger prey, camera traps, species abundance, encounter rate

\section{ABSTRAK}

Taman Nasional Bukit Tiga Puluh merupakan salah satu taman nasional di Indonesia yang dijadikan sebagai kawasan konservasi harimau sumatra. Keberadaan harimau sumatra tidak lepas dari kemampuan kawasan hutan menyediakan komponen habitat, seperti sumber makanan, air, dan tempat berlindung. Penelitian ini bertujuan untuk mengidentifikasi jenis satwa dan kelimpahan jenis satwa mangsa harimau sumatra di Resort Talang Lakat Taman Nasional Bukit Tiga Puluh. Data 

Vol. 17 No. 1 Januari 2022

dikumpulkan dengan camera trap sebagai data primer dan data sekunder dikumpulkan di Balai Taman Nasional Bukit Tiga puluh. Data dianalisis menggunakan rumus kelimpahan jenis dan tingkat perjumpaan. Berdasarkan hasil data, ada lima jenis satwa mangsa harimau sumatra yang terekam kamera trap pada tahun 2020, yaitu beruang madu (Helarctos malayanus), beruk (Macaca nemestrina), kuaw raja (Argusiana argus), landak (Hystrix Brachyura), dan kijang (Muntiacus muntjak). Jenis satwa mangsa dengan kelimpahan jenis dan nilai RAI tertinggi pada tahun 2020 adalah beruk (Macaca nemestrina) dengan nilai kelimpahan jenis 40\% dan RAI 14 foto/hari, sedangkan nilai kelimpahan jenis terendah adalah beruang madu (Helarctos malayanus) dengan nilai $7 \%$ dan RAI 5 foto/hari.

Kata kunci : satwa mangsa harimau sumatra, kamera jebak, kelimpahan jenis, tingkat perjumpaan

\section{PENDAHULUAN}

Harimau sumatra (Panthera tigris sumatrae) merupakan salah satu subspesies dari delapan subspesies harimau (Panthera tigris) dunia yang penyebarannya terbatas hanya ada di Indonesia tepatnya Pulau Sumatra. Dua subspesies lain yang ditemui di Indonesia yaitu harimau jawa telah dinyatakan punah sekitar tahun 1980 sedangkan harimau bali pada tahun 1937. Lembaga dunia pemerhati konservasi sumber daya alam yaitu The International Union for Conservation of Nature and Resource (IUCN) sejak tahun 1996 telah mengkategorikan harimau sumatra sebagai salah satu jenis satwa yang sangat terancam punah (critical endangered). Dalam Convention International of Trade Endangered Species of Flora and Fauna (CITES), harimau sumatra termasuk jenis langka yang masuk dalam kategori apendiks I. Pemerintah Indonesia melalui PP nomor 7 tahun 1999 menetapkan karnivora ini sebagai satwa yang dilindungi.

Keberadaan harimau sumatra yang terbatas hanya di Pulau Sumatra menjadikannya rentan terhadap gangguan dan tekanan habitat. Pulau Sumatra sendiri telah teridentifikasi 12 bentang alam yang ditetapkan sebagai kawasan konservasi harimau. Dua di antara 12 bentang alam ini dikategorikan dalam prioritas global yaitu bentang alam Kerinci Seblat dan Bukit Tiga Puluh.

Bentang alam Bukit Tiga Puluh yang memiliki prioritas global dalam konservasi harimau sumatra (Dephut, 2007), tercakup di dalamnya adalah kawasan Taman Nasional Bukit Tiga Puluh. Keberadaan harimau sumatra di dalam kawasan tidak terlepas dari kemampuan kawasan untuk 
menyediakan komponen habitat. Pakan, air dan cover merupakan komponen habitat yang penting bagi satwa disamping persyaratan khusus seperti tempat mengasin dan berkubang bagi herbivora (Putri, 2010). Ketersediaan komponen tersebut pada sebuah ekosistem menjadi penentu suatu jenis satwa untuk mampu bertahan hidup. Harimau sumatra memerlukan pakan (mangsa), air dan cover untuk bertahan hidup. Ketersediaan satwa mangsa dapat menjadi prioritas untuk memenuhi komponen habitat utama disamping air dan vegetasi yang lebat sebagai tempat berlindung bagi harimau. Vegetasi yang lebat juga mendukung terpenuhinya cover bagi satwa herbivora yang merupakan mangsa harimau sumatra. Kondisi seperti dijabarkan diatas hanya dapat ditemui pada hutan alam atau hutan sekunder yang mencapai suksesi klimaks.

Salah satu upaya untuk mendukung konservasi harimau sumatra di habitat alami yaitu dengan menjaga ketersediaan satwa mangsanya. Perlu dilakukan penelitian untuk mengetahui kelimpahan satwa mangsa harimau sumatra di Taman Nasional Bukit Tiga Puluh. Penelitian ini dilakukan dengan memanfaatkan kemajuan teknologi dalam memonitoring satwa yaitu menggunakan kamera jebak.

Penggunaan kamera jebak ini bertujuan untuk mengetahui jenis satwa dan jumlah satwa yang terekam dalam kamera tersebut, dengan demikian dapat diketahui ketersediaan atau kelimpahan satwa mangsa harimau sumatra di Taman Nasional Bukit Tiga Puluh. Kamera jebak akan dipasang di Resort Talang Lakat Taman Nasional Bukit Tiga Puluh. Resort Talang Lakat dipilih sebagai lokasi pemasangan kamera jebak karena dianggap memiliki akses paling mudah dibandingkan resort lainnya di Taman Nasional Bukit Tiga Puluh.

\section{METODE PENELITIAN}

Penelitian ini dilaksanakan di Resort Talang Lakat Taman Nasional Bukit Tiga Puluh. Penelitian ini dilaksanakan pada bulan Agustus - Oktober tahun 2020.

Alat yang digunakan pada penelitian ini adalah lima kamera jebak (camera trap) Bushnell, GPS (Global Positioning System), laptop yang dilengkapi dengan Microsoft Excel 2010, parang, tali, pita ukur, alat tulis dan kamera digital. Bahan pada penelitian ini yaitu satwa yang akan diamati menggunakan kamera jebak. 

Vol. 17 No. 1 Januari 2022

Data satwa mangsa harimau sumatra dikumpulkan dengan menggunakan metode kamera jebak. Kamera jebak digunakan sebagai alat untuk menentukan jenis dan satwa pada suatu daerah. Metode ini lebih efektif dibandingkan dengan menghitung secara manual. Benda ini juga dapat digunakan untuk mengidentifikasi spesies baru atau langka yang belum di dokumentasi dengan baik sehingga kesejahteraan dan kelangsungan hidupnya dapat diamati secara berkelanjutan (Jaya, 2016).

Data satwa mangsa harimau sumatra yang diperoleh dari kamera jebak, dihitung kelimpahan jenisnya menggunakan persamaan Brower dan Zar (1997). Selain kelimpahan jenis, tingkat perjumpaan ( $R A I)$ dihitung menggunakan persamaan O'Brien, Kinnaird, dan Wibisono (2003). Untuk mengetahui kondisi habitat dilakukan pula analisis vegetasi di sekitar kamera jebak.

Hasil kamera jebak tiga tahun terakhir di lokasi yang sama juga dikumpulkan untuk mengetahui tingkat keberadaan satwa mangsa di lokasi tersebut. Data ini diperoleh dari hasil laporan monitoring satwa yang ada di Balai Taman Nasional Bukit Tiga Puluh.
Parameter yang diamati yaitu jenis satwa mangsa harimau sumatra yang terekam pada lima kamera jebak selama waktu pengamatan 90 hari dan digabungkan dengan data olahan tahun yang sama. Jenis satwa mangsa utama harimau sumatra berdasarkan literatur yang diperoleh adalah rusa sambar (Cervus unicolor), babi hutan (Sus scrofa), dan kijang (Muntiacus muntjac). Sedangkan satwa mangsa alternatifnya adalah kancil (Tragulus sp), beruk (Macaca nemestrina), landak (Hystrix brachyura), trenggiling (Manis javanica), beruang madu (Helarctos malayanus), kuaw raja (Argusianus argus), tapir (Tapirus indicus), kambing hutan (Capricornis sumatrae), napu (Tragulus napu), monyet (Macaca fasicularis), siamang (Symphalagus syndactylus), simpai (Presybytis melalophos), ungko (Hylobates $s p$ ), jelarang (Ratufa bicolor), dan ajag (Cuon alpinus).

\section{Analisis Data}

Analisis data dilakukan menggunakan aplikasi Microsoft Excel 2010. Setiap jenis satwa mangsa harimau sumatra dihitung kelimpahan jenis dan tingkat perjumpaannya untuk dapat dibandingkan kelimpahan setiap jenisnya di Resort 
Talang Lakat Taman Nasional Bukit Tiga

Puluh. Kelimpahan jenis satwa mangsa dihitung menggunakan persamaan (Brower dan Zar, 1997).

$$
P_{s i}=\frac{n_{i}}{N} \times 100 \%
$$

Keterangan :

$\mathrm{P}_{\mathrm{si}} \quad=$ Nilai persen kelimpahan jenis ke-i

$\mathrm{n}_{\mathrm{i}} \quad=$ Jumlah individu jenis ke- $\mathrm{i}$

$\mathrm{N}=$ Jumlah individu seluruh jenis

Tingkat perjumpaan (RAI) satwa mangsa harimau sumatra didapat dari perhitungan total jumlah foto dibagi total hari kamera aktif dikali seratus. Faktor pembagi 100 hari untuk menyamakan waktu satuan usaha yang digunakan (O’Brien, Kinnaird, dan Wibisono, 2003).

$$
\sum E R=\frac{\sum f}{\sum d} \times 100
$$

Keterangan :

ER = Tingkat perjumpaan

$\sum f \quad=$ Jumlah foto yang diperoleh

$\sum d \quad=$ Jumlah total hari operasi kamera

Analisis vegetasi dilakukan untuk menentukan komposisi dan dominasi suatu jenis pohon pada suatu komunitas. Soerianegara dan Indrawan (2002) dalam Putra dan Mulyana (2016) menyatakan bahwa persamaan yang digunakan dalam menentukan komposisi vegetasi adalah sebagai berikut:

a. Kerapatan (K)

$$
\frac{\text { Jumlah individu suatu jenis }}{\text { luas unit contoh }} \times 100 \%
$$

b. Kerapatan Relatif (KR)

$$
\frac{\text { Kerapatan suatu jenis }}{\text { Luas unit contoh }} \times 100 \%
$$

c. Frekuensi (F) $\frac{\text { Jumlah plot ditemukannya suatu jenis }}{\text { Jumlah seluruh plot dalam unit contoh }} \times 100 \%$

d. Frekuensi Relatif (FR)

$$
\frac{\text { Frekuensi suatu jenis }}{\text { Jumlah frekuensi seluruh jenis }} \times 100 \%
$$

e. Dominasi (D)

$$
\frac{\text { Luas bidang dasar suatu jenis }}{\text { Luas unit contoh }} \times 100 \%
$$

Luas bidang dasar suatu jenis $=1 / 4 \pi D^{2}$

f. Dominasi Relatif (DR)

$$
\frac{\text { Dominasi suatu jenis }}{\text { Jumlah dominasi seluruh jenis }} \times 100 \%
$$

g. Indeks Nilai Penting (INP)

$\mathrm{KR}+\mathrm{FR}$ (untuk tingkat semai dan pancang)

$\mathrm{KR}+\mathrm{FR}+\mathrm{DR}$ (untuk tiang dan pohon)

\section{HASIL DAN PEMBAHASAN}

\section{Kondisi Umum Lokasi Penelitian}

\subsection{Kondisi biofisik kawasan}

Taman Nasional Bukit Tiga Puluh merupakan kawasan perbukitan dengan ketinggian 60 - 843 mdpl. Topografi 

Vol. 17 No. 1 Januari 2022

kawasan ini dibagi menjadi tiga bagian yaitu pegunungan dengan lereng sangat curam (>75\%), pegunungan dengan lereng agak curam - sangat curam (25-75\%), dan daratan antar pegunungan dan perbukitan kecil $(<16 \%)$. Kawasan ini termasuk tipe iklim dengan curah hujan tinggi yaitu 2.577 $\mathrm{mm} /$ tahun dengan kelembapan relatif antara 50-90 \%. Jenis tanah kawasan ini sebagian besar adalah Podsolik Merah Kuning dan Latosol Merah (TNBT, 2016).

Resort Talang Lakat merupakan salah satu resort yang terdapat di Seksi Pengelolaan Taman Nasional (SPTN) wilayah II Taman Nasional Bukit Tiga Puluh. Resort Talang Lakat memiliki luas yaitu 12.615,38 Ha. Pos resort ini terletak di Desa Talang Lakat yang merupakan salah satu desa terdekat yang menjadi akses utama ke dalam kawasan Taman Nasional Bukit Tiga Puluh. Secara administrasi Resort Talang Lakat mempunyai batas yaitu

$\begin{array}{ll}\text { Utara } & \text { : Desa Talang Lakat } \\ \text { Selatan } & : \text { Resort Siambul } \\ \text { Timur } & : \text { Resort Siambul } \\ \text { Barat } & \text { : Desa Sungai Akar }\end{array}$

Berdasarkan data zona pengelolaan Taman Nasional Bukit Tiga Puluh tahun 2016, Resort Talang Lakat mencakup zona inti seluas 4.322,11 Ha, zona rimba seluas $6.813,91 \mathrm{Ha}$, zona pemanfaatan seluas 660,73 Ha, dan zona rehabilitasi seluas $818,63 \mathrm{Ha}$.

\subsection{Keberadaan harimau sumatra dan satwa mangsanya}

Faktor yang mempengaruhi keberadaan harimau sumatra salah satunya adalah ketersediaan satwa mangsanya. Berdasarkan data diperoleh terdapat 10 jenis satwa mangsa harimau sumatra yang terdata dari hasil perekaman kamera jebak pada periode tahun 2017-2020 di Resort Talang Lakat Taman Nasional Bukit Tiga Puluh. Tiga di antaranya merupakan satwa mangsa utama harimau sumatra yaitu babi hutan, kijang, dan rusa sambar.

Keberadaan dari satwa mangsa tersebut akan menjaga keberadaan harimau sumatra di Resort Talang Lakat. Hal ini dibuktikan dengan perjumpaan harimau sumatra pada kamera jebak yang telah dipasang. Perjumpaan harimau sumatra ini berbanding lurus dengan masih dijumpainya satwa mangsa di sekitar areal 

Vol. 17 No. 1 Januari 2022

pemasangan kamera jebak di mana terdapat 10 jenis satwa mangsa di lokasi tersebut.

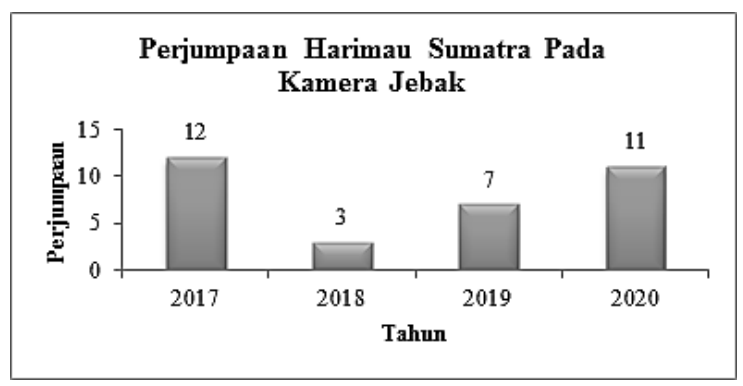

(Sumber : Data olahan 2020)

Gambar 1. Perjumpaan harimau sumatra pada periode 2017-2020

Berdasarkan Gambar 1 diketahui harimau sumatra selalu terekam pada setiap tahun pemasangan kamera jebak di Resort Talang Lakat. Data tersebut membuktikan bahwa harimau sumatra masih ada di Resort Talang Lakat Taman Nasional Bukit Tiga Puluh. Perjumpaan harimau sumatra tersebut tidak dapat menyatakan jumlah sebenarnya dari harimau sumatra di lokasi tersebut dikarenakan perlunya identifikasi pengenalan individu harimau sumatra. Pengenalan individu harimau dilakukan dengan membedakan pola loreng yang khas pada masing - masing individu harimau.

Perjumpaan harimau sumatra yang sama dapat terjadi pada perekaman kamera jebak. Kejadian ini disebabkan harimau sumatra selalu menjaga daerah teritorinya sehingga tidak tertutup kemungkinan bahwa harimau sumatra akan melalui kamera jebak yang terletak di daerah teritorinya berulang - ulang. Perilaku penandaan teritori, pada harimau berkaitan dengan perilaku defekasi (membuang kotoran) yang biasanya diikuti dengan urinisasi (Sriyanto, 2003). Faktor lain yang diduga menjadi penyebab terekamnya harimau sumatra pada kamera jebak secara berulang-ulang adalah tercukupinya kebutuhan makanan di lokasi tersebut sehingga harimau sumatra ini selalu terekam di lokasi yang sama.

Berdasarkan pengamatan harimau sumatra pada hasil rekaman kamera jebak, diketahui bahwa harimau sumatra hidup secara soliter. Hasil tersebut sesuai dengan penelitian Putri (2010) yang menyatakan harimau merupakan pemburu yang soliter, meski kadang harimau jantan bekerja sama dengan betina untuk menggiring dan menyerang mangsa. Perjumpaan harimau sumatra dan satwa mangsanya pada kamera jebak ini hanya sebagai acuan bahwa satwa tersebut masih terdapat di Taman Nasional Bukit Tiga Puluh namun hasil tersebut tidak bisa mengatakan jumlah sebenarnya satwa yang ada di lokasi. Perlu diidentifikasi lebih lanjut untuk mengetahui jumlah sebenarnya 
satwa di lokasi. identifikasi loreng merupakan salah satu identifikasi untuk mengetahui perbedaan individu harimau dan menghitung jumlahnya.

\subsection{Kelimpahan Jenis Satwa Mangsa}

\section{Harimau Sumatra}

Berdasarkan penelitian yang telah dilaksanakan, diperoleh data beberapa jenis satwa mangsa harimau sumatra yang terekam kamera jebak di Resort Talang Lakat Taman Nasional Bukit Tiga Puluh. Data satwa mangsa ini merupakan gabungan satwa mangsa utama dan satwa mangsa alternatif harimau sumatra. Data kelimpahan jenis satwa mangsa harimau sumatra disajikan pada Tabel 1 berikut.

Tabel 1. Kelimpahan jenis satwa mangsa harimau sumatra tahun 2020

\begin{tabular}{cllccc}
\hline No & Nama Satwa & Nama Ilmiah & Famili & $\begin{array}{c}\text { Kelimpahan } \\
\text { Jenis (\%) }\end{array}$ & $\begin{array}{c}\text { RAI } \\
\text { (Foto } \\
\text { /hari) }\end{array}$ \\
\hline \hline 1 & Beruang Madu & Helarctos malayanus & Ursidae & 7 & 5 \\
2 & Beruk & Macaca nemestrina & Cercopithecidae & 44 & 14 \\
3 & Kijang & Muntiacus muntjak & Cervidae & 13 & 10 \\
4 & Kuaw Raja & Argusianus argus & Phasianidae & 12 & 5 \\
S & Landak & Hystrix brachyura & Hystricidae & 24 & 15 \\
\hline
\end{tabular}

Berdasarkan data Tabel 1 diketahui bahwa terdapat lima jenis satwa mangsa harimau sumatra yang terekam oleh kamera jebak di Resort talang lakat pada tahun 2020. Satwa yang terekam oleh lima kamera jebak tersebut adalah beruang madu (Helarctos malayanus), beruk (Macaca nemestrina), kijang (Muntiacus muntjak), kuaw raja (Argusianus argus), dan landak (Hystrix brachyura). Jenis satwa yang memiliki kelimpahan jenis tertinggi dari data tersebut adalah beruk dengan nilai $44 \%$ dan yang terendah adalah beruang madu dengan nilai $7 \%$. Nilai tersebut berbanding lurus dengan nilai RAI, di mana nilai RAI beruk yaitu 14 foto/hari sedangkan nilai RAI beruang yaitu 5 foto/hari.

Tingginya kelimpahan jenis suatu satwa dipengaruhi oleh jumlah satwa tersebut. Beruk yang merupakan satwa yang hidup secara berkelompok diduga akan menyebabkan nilai kelimpahan jenisnya tinggi dibandingkan dengan beruang madu yang merupakan satwa yang hidup soliter. 
Beruk pada hutan yang masih bagus dalam satu kelompoknya mencapai 40 ekor (Wahyono, 2005).

Berdasarkan data kamera jebak tahun 2017-2019 di resort yang sama terdapat jenis satwa mangsa harimau sumatra lain yang terekam kamera jebak. Data satwa mangsa ini merupakan gabungan satwa mangsa utama dan satwa mangsa alternatif harimau sumatra. Data tersebut disajikan pada Tabel 2.

Tabel 2. Kelimpahan jenis satwa mangsa tahun 2017-2020

\begin{tabular}{|c|c|c|c|c|c|}
\hline \multirow{2}{*}{$\mathrm{NO}$} & \multirow{2}{*}{ NAMA SATWA } & \multicolumn{4}{|c|}{ KELIMPAHAN JENIS (\%) } \\
\hline & & 2017 & 2018 & 2019 & 2020 \\
\hline 1 & Babi hutan & 8,5 & 54,1 & 18,8 & - \\
\hline 2 & Beruang madu & 6,7 & 1,9 & 4,5 & 7,4 \\
\hline 3 & Beruk & 48,2 & 32,3 & 36,1 & 43,6 \\
\hline 4 & Kancil & 2,4 & 0,7 & 4,0 & - \\
\hline 5 & Kijang & 11,0 & 5,6 & 12,9 & 12,8 \\
\hline 6 & Kuaw Raja & 2,4 & 1,4 & 1,5 & 11,7 \\
\hline 7 & Landak & 20,1 & 3,1 & 18,3 & 24,5 \\
\hline 8 & Rusa Sambar & - & 0,2 & 0,5 & - \\
\hline 9 & Simpai & 0,6 & 0,3 & - & - \\
\hline 10 & Tapir asia & - & 0,3 & 3,5 & - \\
\hline
\end{tabular}

Sumber : Data olahan (2020)

Terdapat jenis satwa mangsa harimau sumatra lain yang terekam pada tahun 2017-2019 di Resort Talang lakat yaitu babi hutan (Sus scrofa), kancil (Tragulus sp), rusa sambar (Cervus unicolor), simpai (Presybytis melalophos) dan tapir asia (Tapirus indicus). Berdasarkan data tersebut diketahui pada tahun 2017 satwa dengan kelimpahan jenis tertinggi yaitu beruk dengan nilai 48,2\%, pada tahun 2018 satwa dengan kelimpahan jenis tertinggi yaitu babi hutan dengan nilai $54,1 \%$, dan pada tahun 2019 satwa dengan kelimpahan jenis tertinggi yaitu beruk dengan nilai 36, $1 \%$. Satwa yang memiliki kelimpahan jenis tinggi ini merupakan jenis satwa yang hidup berkelompok sehingga jumlah satwa akan mempengaruhi nilai kelimpahan jenis satwa itu pula. 
Wahana Forestra: Jurnal Kehutanan Vol. 17 No. 1 Januari 2022

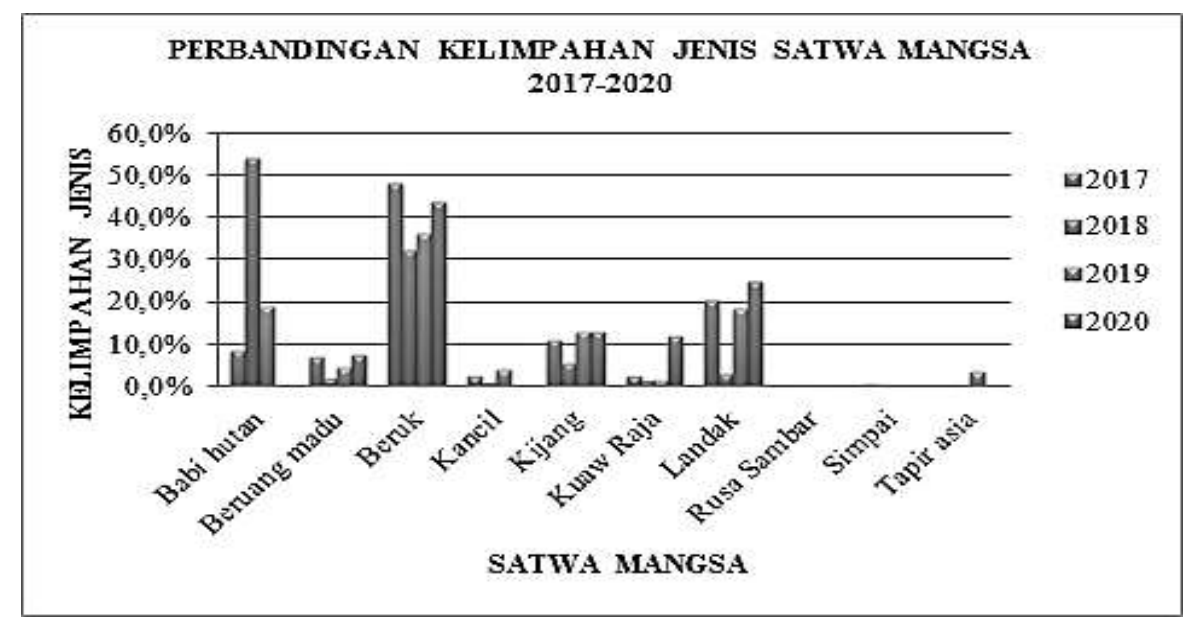

(Sumber : Data olahan 2020)

Gambar 2. Perbandingan kelimpahan jenis 2017-2020

Berdasarkan Gambar 2 diketahui bahwa babi hutan memiliki persentase kelimpahan jenis tertinggi dalam periode 2017-2020 yaitu 54,1\%, akan tetapi jika dirata-ratakan kelimpahan jenis satwa mangsa harimau sumatra yang paling tinggi dalam periode 2017-2020 yaitu beruk. Dilihat dari Gambar 2 tersebut, beruk dijumpai di setiap tahun dengan nilai persentase kelimpahan jenis diatas 30\%. Kelimpahan jenis beruk yang tinggi dipengaruhi oleh jumlah beruk yang terekam dari kamera jebak. Beruk merupakan satwa yang hidup secara berkelompok di mana satu kelompok beruk bisa mencapai 40 ekor (Wahyono, 2005).

\subsection{Satwa Mangsa Utama Harimau Sumatra}

Satwa mangsa utama harimau sumatra menurut Wibisono (2006) dalam Putri (2010) adalah dari famili Cervidae dan famili Suidae. Berdasarkan data pada Tabel 2 diketahui bahwa satwa mangsa harimau sumatra yang termasuk pada dua famili tersebut ialah rusa sambar dan kijang dari famili Cervidae serta babi hutan dari famili Suidae. 


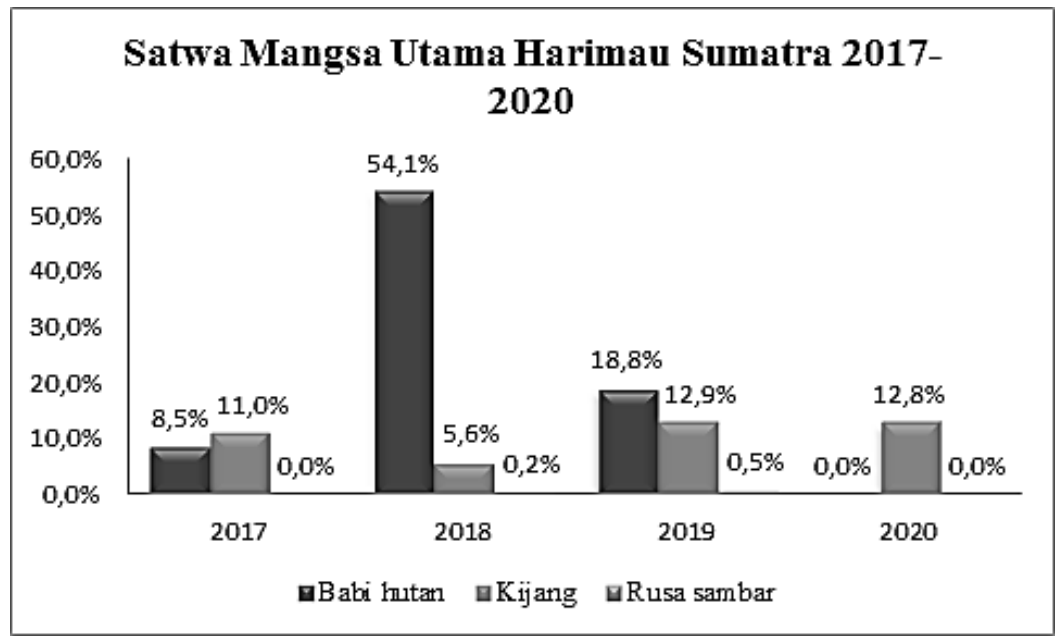

(Sumber : Data olahan 2020)

Gambar 3. Kelimpahan jenis satwa mangsa utama harimau sumatra 2017-2020

Berdasarkan Gambar 3 dapat diketahui bahwa satwa mangsa harimau sumatra dengan kelimpahan jenis tertinggi dari periode 2017-2020 yaitu babi hutan dengan nilai $54,1 \%$ pada tahun 2018 . Tingginya kelimpahan jenis tersebut diduga karena babi hutan merupakan satwa yang hidup secara berkelompok sehingga jumlah mempengaruhi dari analisis kelimpahan jenis babi hutan tersebut. Dilihat dari tingkat perjumpaan satwa mangsa utama harimau sumatra sesuai Gambar 3, satwa yang selalu dijumpai setiap tahunnya adalah kijang.

Keberadaan kijang yang dijumpai setiap tahunnya tentunya didukung dengan pakan yang tersedia. Faktor lain yang mempengaruhi kelimpahan suatu jenis satwa adalah kondisi habitatnya. Heriyanto dan Iskandar (2004) menyatakan bahwa indikator dari habitat yang baik adalah tersedianya sumber pakan yang cukup, baik dari segi kelimpahan jenis ataupun jumlahnya. Tersedianya sumber pakan bagi satwa mangsa harimau sumatra yang sebagian besar merupakan satwa herbivora, maka akan meningkatkan ketersediaan pakan bagi harimau sumatra itu pula.

Kijang lebih menyukai habitat di semak - semak pinggiran hutan tepatnya di daerah terbuka yang banyak ditumbuhi alang - alang muda. Kijang lebih banyak memilih pakan jenis dedaunan dibanding buah - buahan (Farida, Setyorini, dan 
Sumaatmadja, 2003). Pada lokasi peletakan kamera jebak banyak dijumpai jenis dedaunan yang dapat menjadi pakan dari kijang. Pakan tersebut berasal dari dedaunan muda seperti semai pohon ataupun tumbuhan bawah hutan. Pembersihan lokasi di sekitar area kamera jebak menyebabkan cepatnya pertumbuhan semai ataupun tumbuhan bawah baru di sekitar kamera jebak yang menjadi pakan dari kijang.

Berdasarkan hasil analisis vegetasi yang dilakukan, teridentifikasi 11 jenis tumbuhan pada petak contoh yang telah dibuat. Data disajikan pada setiap tingkatan vegetasi yaitu semai, pancang, tiang dan pohon. Data tersebut disajikan pada Tabel 3.

Tabel 3. Hasil analisis vegetasi

\begin{tabular}{lllr}
\hline \multicolumn{1}{r}{$\begin{array}{r}\text { Tingkat } \\
\text { Vegetasi }\end{array}$} & \multicolumn{1}{c}{ Nama Lokal } & \multicolumn{1}{c}{ Nama Ilmiah } & $\begin{array}{r}\text { INP } \\
(\%)\end{array}$ \\
\hline \hline Semai & Keladi & Alocasia sp. & 13 \\
Semai & Mahang Tapak Gajah & Macaranga gigantea & 10 \\
Semai & Meranti & Shorea sp. & 32 \\
Semai & Meranti batu & Shorea platyclados & 43 \\
Semai & Mersawa & Anisoptera sp. & 8 \\
Semai & Pakis & Diplazium esculentum & 86 \\
Semai & Pasak Bumi & Eurycoma longifolia & 8 \\
Pancang & Balik Angin & Mallotus paniculatus & 6 \\
Pancang & Jirak & Symplocos cochinensis & 53 \\
Pancang & Mahang Tapak Gajah & Macaranga gigantea & 9 \\
Pancang & Meranti Batu & Shorea platyclados & 18 \\
Pancang & Mersawa & Anisoptera sp. & 24 \\
Pancang & Pasak Bumi & Eurycoma longifolia & 26 \\
Pancang & Resak & Vatica wallichii & 9 \\
Tiang & Balik Angin & Mallotus paniculatus & 60 \\
Tiang & Jirak & Symplocos cochinensis & 61 \\
Tiang & Mahang Tapak Gajah & Macaranga gigantea & 40 \\
Tiang & Meranti & Shorea spp & 53 \\
Tiang & Meranti Batu & Shorea platyclados & 54 \\
Tiang & Mersawa & Anisoptera sp. & 33 \\
Pohon & Kempas & Koompassia malaccensis & 60
\end{tabular}




\begin{tabular}{llll} 
Pohon & Mahang Tapak Gajah & Macaranga gigantea & 52 \\
Pohon & Meranti & Shorea spp & 55 \\
Pohon & Meranti Batu & Shorea platyclados & 66 \\
Pohon & Mersawa & Anisoptera sp. & 66 \\
\hline Sumber : Data olahan $(2020)$ &
\end{tabular}

Berdasarkan Tabel 3 diketahui bahwa INP tertinggi pada tingkat semai dan tumbuhan bawah yaitu jenis pakis dengan nilai $86 \%$, tingkat pancang yaitu jenis balik angin dengan nilai $62 \%$, tingkat tiang yaitu jenis jirak dengan nilai $61 \%$, dan tingkat pohon yaitu jenis mersawa dan meranti batu dengan nilai 66\%. Pakis merupakan salah satu tumbuhan yang dapat digunakan kijang sebagai pakan, hal ini sesuai dengan pernyataan Setiawan, Mustari, dan Rinaldi (2015) yaitu selain pakis, dedaunan juga dapat digunakan sebagai pakan kijang seperti dedaunan dari ki anak.

\section{KESIMPULAN DAN SARAN}

\section{A. Kesimpulan}

Berdasarkan penelitian yang telah dilakukan dapat disimpulkan terdapat total lima jenis satwa mangsa harimau sumatra yang terekam kamera jebak pada tahun 2020 di Resort Talang Lakat Taman Nasional Bukit Tiga Puluh yaitu beruang madu (Helarctos malayanus), beruk (Macaca nemestrina), kuaw raja (Argusianus argus), dan landak (Hystrix brachyura) sebagai satwa mangsa alternatif harimau sumatra serta kijang (Muntiacus muntjak) sebagai satwa mangsa utama harimau sumatra.

Kelimpahan jenis satwa mangsa harimau sumatra tertinggi pada tahun 2020 yaitu beruk dengan nilai $44 \%$ serta RAI 14 foto/hari. Kelimpahan jenis satwa mangsa harimau sumatra terendah pada tahun 2020 yaitu beruang madu dengan nilai $7 \%$ serta RAI 5 foto/hari.

\section{B. Saran}

Perlu dilakukannya penelitian lanjutan tentang kelimpahan jenis satwa mangsa pada resort lain di Taman Nasional Bukit Tiga Puluh. Perihal ini bertujuan untuk diketahuinya jenis satwa mangsa harimau sumatra di semua resort Taman Nasional Bukit Tiga Puluh. 


\section{DAFTAR PUSTAKA}

Brower, J.E., dan J.H. Zar. 1997. Field and Laboratory Methods for General Ecology. Dubuque, Iowa: Wm. C. Brown Company Publisher.

[Dephut] Departemen Kehutanan. 2007. Strategi dan Rencana Aksi Konservasi Harimau Sumatera (Panthera tigris sumatrae). Jakarta.

Farida, Wartika Rosa, Liliy Endang Setyorini, dan Gozali Sumaatmadja. 2003. Habitat dan Keragaman Tumbuhan Pakan Kancil (Tragulus javanicus) dan Kijang (Muntiacus muntjak) di Cagar Alam Nusakambangan Barat dan Timur Nusakambangan. Biodiversitas Journal of Biological Diversity 4(2): 97-102.

Heriyanto, N.M., dan Sofian Iskandar. 2004. Status Populasi dan Habitat Surili (Presbytis comata Desmarest) di Kompleks Hutan Kalajaten, Karangranjang, Taman Nasional Ujung Kulon. Penelitian Hutan dan Konservasi Alam 1(1): 89-98.

Jaya, M.A. 2016. Rancang Bangun Camera Trap dengan Pengiriman Video Secara Real - Time. Skripsi Jurusan Teknik Elektro, Fakultas Teknik Universitas Lampung.

O'Brien, Timothy G., Margaret F. Kinnaird, dan Hariyo T. Wibisono. 2003. Crouching Tigers, Hidden Prey: Sumatran Tiger and Prey Populations in a Tropical Forest Landscape. Animal Conservation 6(2): 131-39.
Putra, Erianto Indra, Dadan Mulyana, dan Lody Junio. 2016. Komposisi Vegetasi Pada Lahan Bekas Terbakar di Hutan Pendidikan Gunung Walat. Jurnal Silvikultur Tropika 7(2): 12532.

Putri, Astri Meirani Mulyono. 2010. GIS dan Remote Sensing Untuk Analisis Kesesuaian Habitat Harimau Sumatera (Panthera tigris sumatrae) di TN Bukit Tigapuluh dan Sekitarnya. Tesis Program Pascasarjana, Institut Pertanian Bogor.

Setiawan, Agus, A.H. Mustari, dan D. Rinaldi. 2015. Kelimpahan Jenis Mamalia Menggunakan Kamera Jebakan di Resort Gunung Botol Taman Nasional Gunung Halimun Salak. Media Konservasi 20(2): 93101.

Sriyanto. 2003. Kajian Satwa Mangsa Harimau Sumatra (Panthera tigris sumatrae, Pocock 1929) di Taman Nasional Way Kambas Lampung. Program Pascasarjana, Institut Pertanian Bogor.

[TNBT] Balai Taman Nasional Bukit Tiga Puluh. 2016. Zona Pengelolaan Taman Nasional Bukit Tiga Puluh Riau-Jambi. Rengat.

Wahyono, Edy Hendras. 2005. Mengenal Beberapa Primata di Provinsi Nangroe Aceh Darussalam. Jakarta: Conservation International Indonesia. 